\title{
DEVELOPMENT OF SMALL AND MEDIUM-SIZED ENTERPRISES IN REGIONS OF LATVIA
}

\author{
Inese Ratanova ${ }^{1}$, Galina Reshina ${ }^{2}$, Silvija Bruna ${ }^{3}$, Eduards Gross ${ }^{4}$ \\ Baltic International Academy (Latvia), University of Latvia (Latvia)
}

\begin{abstract}
For successful economic transition to the new stage of development improvements in business environment, as also the entrepreneurs who are ready to start your own business and to set up new companies. One of the main challenges the EU Member States face is the need to boost their level of entrepreneurship and to become more competitive in the global market. That was one of the main objectives set by the Lisbon European Council, in March 2000, with a view to improving the Union's performance in terms of employment, economic reform and social cohesion. Entrepreneurship is not only a driving force in the creation of new jobs, but it also increases and enhances competitiveness and growth, personal fulfilment and the achievement of social objectives. The authors pay specific attention to the need to examine factors that affect the business environment development and entrepreneurship in regions of Latvia, which determinethe complexity of the existing conditions and factors in each region in Latvia.

KEYWORDS: regional development, small and medium-sized enterprises.
\end{abstract}

JEL CODES: O180

\section{Introduction}

The main purpose of economic development inmost countries and regions is to improve the quality of life. Also, the present day economics focuses on such important aspects of socio-economic development as increasing the degree of economic freedom of the people, by creating conditions conducive to the growth of people's self-esteem as a result of the formation of social, political, economic and institutional systems focused on human dignity. Latvian government is committed to improve business environment, entrepreneurship development, increase the proportion of small and medium-sized enterprises (SME) in the economy of Latvia and therefore extremely interested in stable operation of such enterprises and increaseintheir numbers. There are a number of activities within the framework of structural funds of the European Union, such as the European regional development fund, the European Social Fund, the Cohesion Fund.

The experience of countries with developed market economies shows that solving socio-economic problems depends largely on the level of development of SME category enterprises. The development of regions, territories and cities depends on the level of economic activity of merchants and businesses. Differ-

1 Inese Ratanova - Baltic International Academy, Faculty of Business Administration, Lecturer. Scientific interests:

Entrepreneurship Development, SMEs Development, Regional Development

E-mail: inese.ratanova@bsa.edu.lv

Tel.: +371 67100232

2 Galina Reshina - Baltic International Academy, Faculty of Business Administration, Professor. Scientific interests: EU Budget, The State Budget, Regional Development

E-mail: reshinaganna@inbox.lv

3 Silvija Bruna - University of Latvia, Lecturer. Scientific interests: project management

E-mail: silvija.bruna@lu.lv

4 Eduards Gross - University of Latvia, PhD Student. Scientific interests: Government finances, the State budget

E-mail: eduards.gross@inbox.lv 
ences in the level of territory development on the one hand are an impediment to business development, and on the other hand inhibit the development of the regions. The results of the study indicate that for most small businesses in Latvia survival is the problem, we observe an increase in the number of micro enterprises and also a decreasing number of small and medium-sized companies.

The purpose of this article is to identify the factors of business environment restricting the business activity of SMEin Latvia in the context of regions, to show the trends in the context of the current economic situation and the level of development in the planning regions.

The object of the research isSMEin Latvia.

In order to achieve paper aim, the tasks include identify the factors of business environment, analyze SME in Latvia in the context of regions, analyze differences in the development of Latvian regions.

The methodological basis for the article is made up of data analysis, statistical data analysis, and refers to the laws, regulations, and guidelines of the Republic of Latvia as well as works of foreign authors, and research carried out by the authors. The listing of literature provides references to works of Latvian and international authors, and sources of publicly available information.

\section{Entrepreneurshipand entrepreneurship environment}

A systematic approach to the evaluation of entrepreneurship emerged only at the end of XVII - beginning of XVIII century. The concept of "entrepreneur" and "entrepreneurship" was usedfor the first time in the modern sense by the English economist Richard Cantillon (Blaug, 1994: 616). Cantillon first introduced the scientific use of the term "entrepreneur" as denoting the person buying goods for a known price, and selling for anunknown price, and therefore someone who is taking a risk. The most popular theory of the basic concept of entrepreneurship is that of Schumpeter, combining economic assessment of the entrepreneurial function with an attempt to display a psychological portrait of the entrepreneur and entrepreneurship as a process of "creative destruction". "Entrepreneurs we call business entities whose function is the implementation of new combinations and who acts as active subjects of the enterprise". Schumpeter identified three main groups of motives: the desire to be the absolute owner of one' senterprise; the desire to prove its own consistency; the ability to realize oneself, the ability to do things you love and achieve concrete results on one's own; the joy of creation, which makes for an independent business activity (Schumpeter, 1982: 63).

A company operates in a specific business environment, which has an impact on all of its activities. The business environment is characterized by the current economic and political climate, legal, socio-cultural, technological, geographical environment, the environmental situation and the state of the institutional and information systems. The economic situation determines the income and purchasing power of the population, the level of unemployment and employment, the degree of economic freedom of entrepreneurs, investment opportunities, availability and accessibility of financial resources and other economic factors.

The political situation depends on the goals and objectives of the government in power. The political situation depends on the goals and objectives of the government of the country. Through the economic policy, the government can influence entrepreneurial activity in specific sectors or regions. The legal environment is characterized by a system of laws and regulations governing the trade, business, industrial, financial, tax, investment, and innovation areas of the company. Level of a legal framework for entrepreneurship largely determines the stability and sustainability of the enterprise.

Geographical environment determines the natural environment in which the business, such as availability of raw materials, energy, climate and seasonal conditions, availability of highways, railways, sea and air routes. Geographical factors are taken into account when supply of raw materials, finished goods distribution, etc. Ecological situation reflects the state of the environment, the degree of environmental risk, elaboration of monitoring and enforcement measures on businesses that pollute the environment. These and other environmental factors are taken into consideration when choosing a company of a certain technology, the raw materials used or the type of products. The institutional environment is characterized by a variety of institutions (organizations), with the help of which a range of commercial transactions, business relation- 
ships are established. Such institutions include banks, insurance companies, stock exchanges, companies that provide a variety of professional services (legal, accounting, auditing, etc.), advertising agencies, employment agencies, etc.

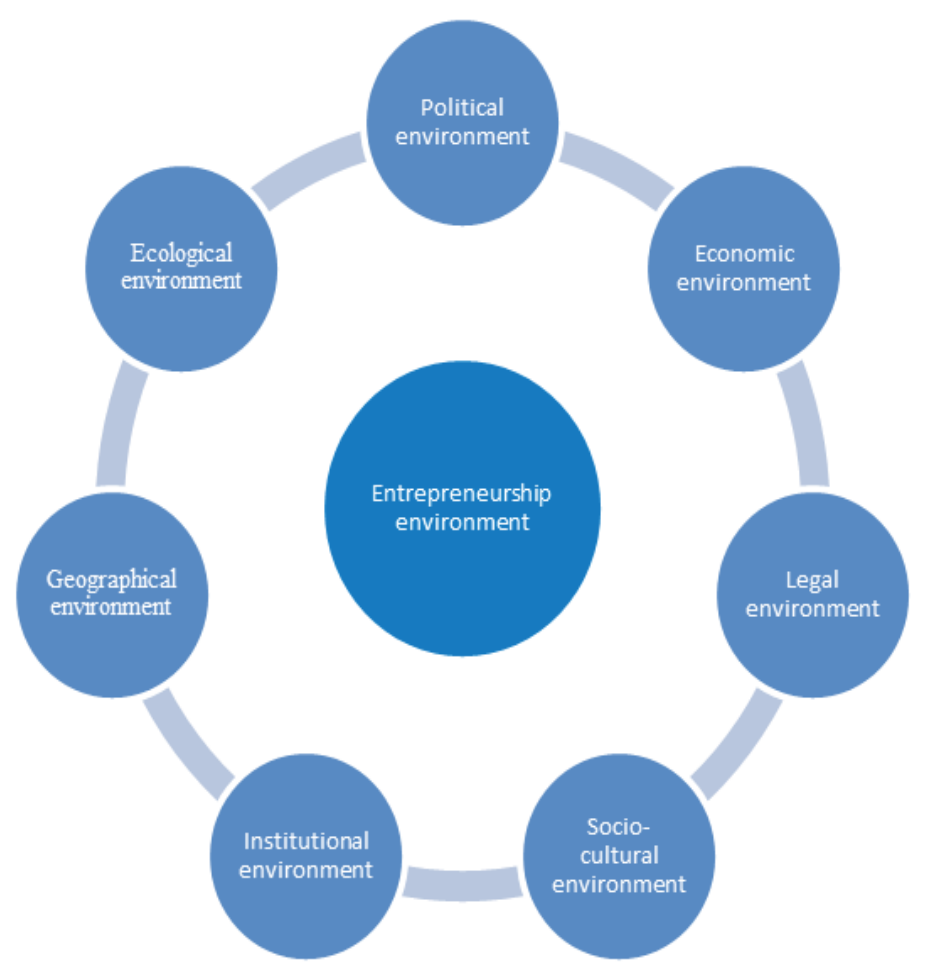

Figure 1. Factors of business environment

Source: prepared by the authors

Daniel Isenberg looks at the entrepreneurship as an ecological system that demonstrates the interdependence of environmental factors and is composed of many elements with complex relationships. The interdependence of ecosystem factors is the nature of complex cause-and-effect relationships; the interaction between the factors is influenced by the entrepreneurial activity in the region. Due to the complexity and combinations of ties, their successful interface requires:

- Supportive policies.

- Markets.

- Capital.

- Skills and abilities of the people.

- The culture of entrepreneurship.

- Supporting tools.

Each element contributes to the development of the entrepreneurship ecosystem. Sustainable development and growth of the entrepreneurship is ensured by the combination of all these factors. In the center of the ecosystem of entrepreneurship are the factors of its form and evolve. The complexity and uniqueness of the conditions existing in each country, region cause the need to study the factors that influence the creation of a favorable business environment as an ecosystem (Isenberg, 2011).

\section{Small and medium sized enterprises in Latvia}

The basis of national competitiveness is the existence of competitive businesses, whose success depends on the factors of entrepreneurship environment. For successful economic transition to a new stage of devel- 
opment it is necessary to solve a series of questions, and first of all we need entrepreneurs who are ready to start their own business and to set up new companies. More than $99 \%$ of businesses in Europe are SME that employ more than a half of the employed. SME development is especially important in the situation of economic downturn and increased unemployment. A wide range of external and internal factors, including the situation in the world, political trends, specific personal qualities, etc. affect the business and enterprise spirit. The World Bank's international research Doing Business, as well as the Study of Administrative Procedure Impact upon Business Environment show the opinion of entrepreneurs about the factors hindering their activity. Latvia has achieved significant progress in improving business environment - Latvia has improved its rank in the World Bank's research Doing Business 2012 by 10 positions, moving from $31^{\text {st }}$ place (Doing Business, 2011) to $21^{\text {st }}$ (Doing Business, 2012), of 183 world countries (Ministry of Economics Republic of Latvia, 2011: 125-126). The World Bank's Doing Business 2013 index ranks Latvia 25 ${ }^{\text {th }}$ among 185 countries, or $8^{\text {th }}$ among the EU member states. In 2012, Latvia experienced a trend of growing numbers of registered companies, compared to the number of ones liquidated over the last four years. It is important to encourage activity not only of the existing companies, but also support starting of new businesses and employment providers.

The entrepreneurship development policy in Latvia basically aims to increase business activity and improve the competitiveness of enterprises. Development of small businesses in Latvia contributes to the creation of an enabling environment for economic recovery, such as developing the competitive environment, creating more jobs, structural adjustments, increasing consumer sector, and reducing monopolization of the market (SME policies in EU, 2004). This sector of economy creates the necessary atmosphere of competition, is able to quickly respond to any market changes (SME EC initiatives and programmes, 2004). The personal backgrounds of the individuals who undertake industrial activity are strongly influenced by several internal and external factors including the world situation, political trends, etc. Thus, a multitude of factors affect people's entrepreneurial spirit and they, in turn, cast their influence on their environment (Pande, 2009: 137). In order to foster development of SME and the overall business environment, the policy is formed and implemented in three directions: development and implementation of promotion of micro-enterprise establishment and development support measures; measures to promote business start-ups; providing enterprises access to finance.

The global economic crisis and its consequences became visible in virtually all sectors of small businesses, which employ a significant portion of the population of Latvia. For the countries of the European Union and most other countries, this policy is an integral part of economic and social policies, as a set of activities that stimulate economic growth and also help in addressing many social problems, such as unequal distribution of income, unemployment, low participation of society in economic processes. In Latvia, the SME play a significant role in the building of the gross domestic product (GDP) and the labor market. At the legislative level, a SME is governed by the Commercial Law, and the Civil Law.In Latvia, just as elsewhere in Europe, SME form a major part of the national economy and play a significant role in building the GDP and in employment. The definition of SME is stipulated in the Law on Control of Aid for Commercial Activity, Regulations No 964 of the Cabinet of Ministers of November 25, 2008 Regulations on Declaration Procedures of Commercial Companies According to Small or Medium-sized Commercial Company, and Commission Regulation (EC) No 800/2008: medium-sized enterprises (number of employees: 50-249; annual turnover does not exceed EUR 50 million; total sum of annual balance is under EUR 43 million); small enterprises (number of employees: 10-49; annual turnover does not exceed EUR 10 million; total sum of annual balance is under EUR 10 million); micro enterprises (number of employees: 1-9; annual turnover does not exceed EUR 2 million; total sum of annual balance is under EUR 2 million) (Economic Development of Latvia, 2012). An important indicator characterizing economic activity is the number of economically active merchants and commercial companies per 1000 inhabitants. This indicator in Latvia has grown constantly over the last 10 years from 17 in 2001 to 32 in 2010 and 38 in 2011.

According to the information of the Central Statistical Bureau (CSB), there were 80,484 economically active individual merchants and commercial companies in Latvia in 2011 (excluding farms, fish farms, and 
self-employed persons involved in economic activity), $99.53 \%$ of which belonged to the category of SME. The distribution of economically active SME in Latvia is the following: micro-enterprises $-84.72 \%$, small enterprises $-12.29 \%$, medium-sized enterprises $-2.52 \%$, large enterprises $-0.47 \%$. The data in the table 1 clearly demonstrates that the percentage of micro enterprises is increasing. But at the same time it means that an enterprises size reduction is taking place; we see that the percentage of the small and medium enterprises is substantially falling. According to the statistics of the Register of Enterprises in the year 2011, 19942 subjects were registered and 4041 subjects were removed from the records of the Register of Enterprises. By December 11, 2012, 17780 subjects were registered and 4078 subjects were excluded from the records of the Register of Enterprises.

Table 1. Dynamics of active merchants and commercial companies in relation to the total number of registered subjects in Latvia (2005-2011) (\%)

\begin{tabular}{|l|l|l|l|l|l|l|l|}
\hline Category of enterprises & $\mathbf{2 0 0 5}$ & $\mathbf{2 0 0 6}$ & $\mathbf{2 0 0 7}$ & $\mathbf{2 0 0 8}$ & $\mathbf{2 0 0 9}$ & \multirow{2}{*}{$\mathbf{2 0 1 0}$} & $\mathbf{2 0 1 1}$ \\
\hline Micro & 78.1 & 77.7 & 76.9 & 78.6 & 82.5 & 83.9 & 84.72 \\
\hline Small & 17.8 & 17.9 & 18.7 & 17.3 & 14.1 & 12.9 & 12.29 \\
\hline Medium & 3.6 & 3.8 & 3.8 & 3.5 & 2.9 & 2.7 & 2.52 \\
\hline Large & 0.5 & 0.6 & 0.6 & 0.6 & 0.5 & 0.5 & 0.47 \\
\hline
\end{tabular}

Source: prepared by the authors based on the data of the CSB

Figure 2 shows that the peak in the number of registered and closed enterprises are closest in 2007 . That year 14208 subjects were registered and 11186 enterprises closed. In 2008 and 2009, there was a steady trend of reduction in the number of registration of new enterprises and the increase in the number of those closing. In 2010 the registration of new enterprises increased, but so did the number of closed enterprises. This trend correlates with the growth in the number of micro-enterprises and also with the reducing numbers of the small and medium-sized companies. 2011 shows a positive trend, the number of registered subjects exceeding that of the closed subjects.

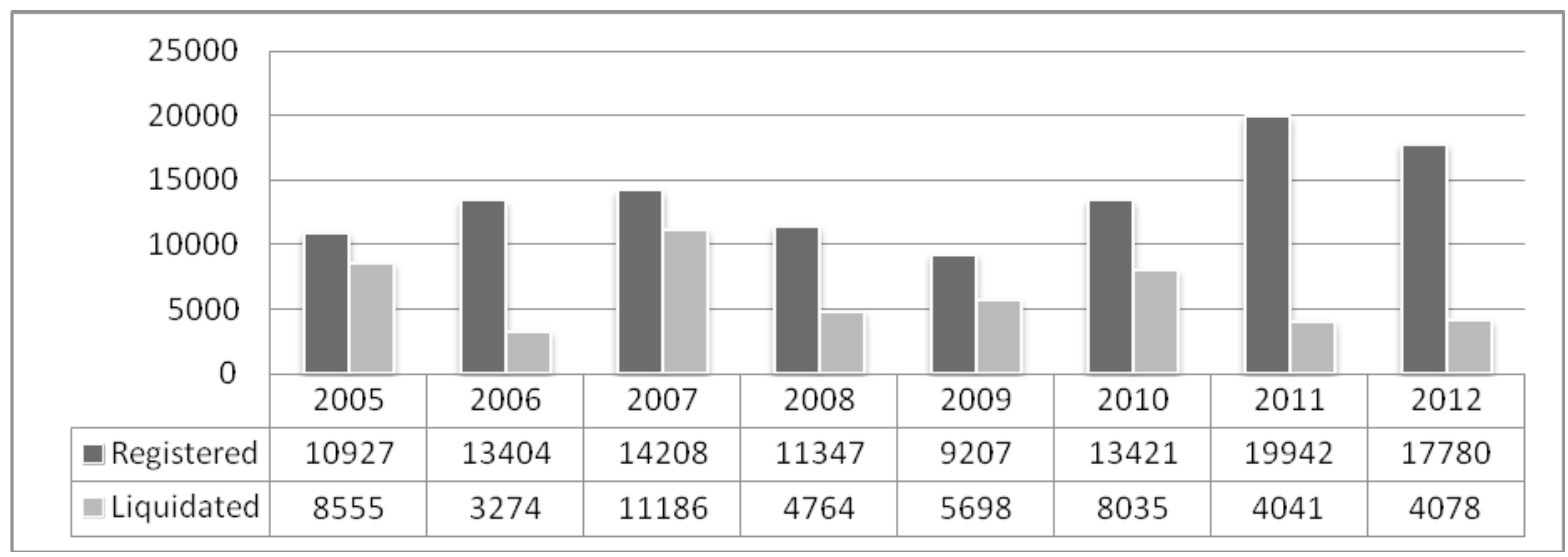

Figure 2. Dynamics of registered and liquidated subjects (2005-2012), units

Source: prepared by authors on the base of data's of the Central Statistical Bureau Register of Enterprises and Commercial Register

As of May 1, 2010, a law came into force that governs the procedure for the establishment of microenterprises with statutory funds of one lat and reduced-rate registration fees, which greatly simplifies the process of creating microenterprises. It should be noted that the entry into force of the new law for micro businesses influenced the increase in the number of such enterprises. But it is also clear that there are other causes that have contributed to this process. An important reason was the sharp decline in access to bank loans. The economic crisis has made it more difficult for SME to access bank credit. The proportion of unsuccessful loan 
applications rose, the largest increase in unsuccessful loan applications was observed in Latvia between 2007 and 2010 (from $4 \%$ to $26 \%$ ) (The proportion of unsuccessful loan applications by SMEs has risen with the economic crisis, 2011).

\section{Differences in the development of Latvian regions}

The development of aregion is a multi-dimensional and multi-faceted process, which is considered of various social and economic objectives. Socio-economic development includes issues such as increasing production and income, changes in the institutional, social and administrative structures of society, changes in the public consciousness, changes in traditions and habits. The main components of the process of socioeconomic development are higher incomes, better health, and higher educational and cultural level. Currently, the main purpose of economic development of most countries and regions is to improve the quality of life.

The GDP can be considered one of the main indicators of the economic development of a territory. The GDP of a country is the sum total of the finished products and services produced within its territory in one year, also including the output produced y the country's residents abroad.

Table 2. GDP in the planning regions in 2005-2009, in actual prices, LVL

\begin{tabular}{|l|l|l|l|l|l|}
\hline \multicolumn{1}{|c|}{ Planning regions } & \multicolumn{1}{|c|}{$\mathbf{2 0 0 5}$} & \multicolumn{1}{c|}{$\mathbf{2 0 0 6}$} & \multicolumn{1}{c|}{$\mathbf{2 0 0 7}$} & \multicolumn{1}{c|}{$\mathbf{2 0 0 8}$} & \multicolumn{1}{c|}{$\mathbf{2 0 0 9}$} \\
\hline Riga region & 6199415 & 7642389 & 9854483 & 10932150 & 8630995 \\
\hline Vidzeme region & 563908 & 733130 & 990399 & 985559 & 899182 \\
\hline Kurzeme region & 965196 & 1149313 & 1517697 & 1670567 & 1387185 \\
\hline Zemgale region & 629684 & 805037 & 1180164 & 1196876 & 1035389 \\
\hline Latgale region & 691460 & 831952 & 1219612 & 1267435 & 1092337 \\
\hline Total & $\mathbf{9 0 5 9 0 8 7}$ & $\mathbf{1 1} \mathbf{1 7 1 ~ 6 9 3}$ & $\mathbf{1 4 7 7 9 8 1 0}$ & $\mathbf{1 6 0 8 4 6 7 8}$ & $\mathbf{1 3 0 7 0 4 4 8}$ \\
\hline
\end{tabular}

Source: prepared by the authors based on the data of the Central Statistical Bureau

The breakdown of GDP across the planning regions clearly highlights the obvious domination of the Riga region in the Latvian economy: the 2009 GDP of the Riga planning region accounted for two thirds, or $66 \%$, of the total GDP. The share of the other regions in the gross domestic product ranged between $6.9 \%$ (Vidzeme region) to $10.6 \%$.

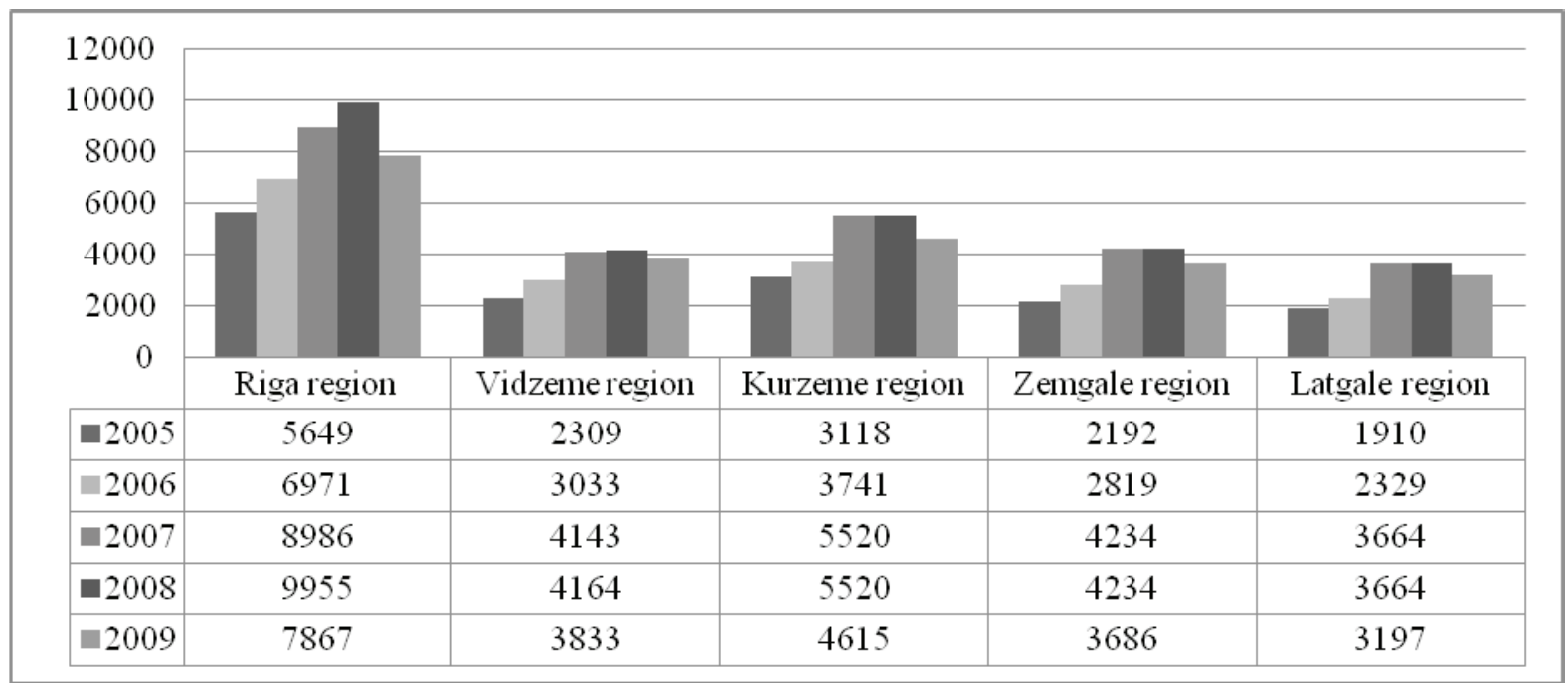

Figure 2. Per GDP in the planning regions in 2005-2009, in actual prices, LVL, and \% compared to the national average

Source: prepared by authorsbased on the data of the Central Statistical Bureau 
The Riga region showed the highest value in 2009, LVL 7867, which is $135.7 \%$ of the national average. The per capita GDP figures of the other regions of Latvia were below the national average. In 2009, the Kurzeme region had the second highest figure, LVL 4615 (79.6 \% of the national average), followed by the Vidzeme region with LVL 3833 (66.1\% of the national average). In Zemgale, the GDP per capita was slightly lower than in Vidzeme: LVL 3686 in 2009 (or $63.6 \%$ of the national average). Latgale had the lowest per capita GDP figure in 2009, LVL 3197 (55.1\% of the national average). Regional disparities in the per capita GDP decreased in 2009 compared to the preceding year.

An indicator used to describe economic activity within a territory is the number of economically active statistical units of the market sector and the number of individual merchants and commercial companies.

Table 3. Number of economically active market sector statistical units per 1000 inhabitants in the planning regions in 2006-2010

\begin{tabular}{|l|l|l|l|l|l|}
\hline \multicolumn{1}{|c|}{ Planning regions } & \multicolumn{1}{|c|}{$\mathbf{2 0 0 6}$} & \multicolumn{2}{c|}{$\mathbf{2 0 0 8}$} & $\mathbf{2 0 0 9}$ & $\mathbf{2 0 1 0}$ \\
\hline Riga region & 55.7 & 61.0 & 60.2 & 63.2 & 66.3 \\
\hline Vidzeme region & 57.1 & 60.4 & 59.0 & 59.3 & 62.6 \\
\hline Kurzeme region & 50.4 & 54.9 & 53.0 & 54.0 & 57.3 \\
\hline Zemgale region & 47.0 & 50.1 & 46.9 & 44.8 & 50.3 \\
\hline Latgale region & 44.0 & 47.5 & 47.7 & 48.4 & 50.5 \\
\hline Average & $\mathbf{5 2 . 2}$ & $\mathbf{5 6 . 7}$ & $\mathbf{5 5 . 6}$ & $\mathbf{5 7 . 0}$ & $\mathbf{6 0 . 4}$ \\
\hline
\end{tabular}

Source: State Regional Development Agency, 2011: 32

In order to enable comparison between territories based on aggregate indicators, a synthetic index needs to be used comprising a variety of indicators. A territorial development index has been used in Latvia for the assessment of the level of development of various territorial units for more than a decade, now referred to as the territorial development level index. Its origins and purpose are associated with the earliest methodology for identifying potential regions (territories) subject to special assistance, which was developed in 1997 by the Latvian Statistical Institute. The current procedures for calculating the territorial development level index and the territorial development level change index have been laid down by Cabinet Regulation No 482 of May 25, 2010, "Regulations on the Procedures for Calculating the Territorial Development Index and Its Values". Standardisation of the main development indicators is at the foundation of the method for calculating the territorial development level index. The standardised indicators are calculated from initial indicators which characterise a territory in various aspects and are expressed in real measureable units (number of people, money, interest rates, and other measureable units). As a result of standardisation, the initial measurement units of the indicator disappeared, rendering the various indicators mutually comparable. The standardised indicators are combined creating the overall development level index. A standardised value is calculated for each main development indicator and for each territory. Just as in 2009 and 2010, there were five cities in the group of the country's cities in 2011 with a positive value of the territorial development level index: Riga, Jelgava, Jurmala, Valmiera and Ventspils. The remaining four cities showed negative index values of varying magnitude, i.e., their values were below the average in the city group.

Table 4. The territorial development level index of planning regions

\begin{tabular}{|l|l|l|l|l|l|l|}
\hline \multirow{2}{*}{\multicolumn{1}{c|}{ Regions and Cities }} & \multicolumn{2}{c|}{$\mathbf{2 0 0 9}$} & \multicolumn{2}{c|}{$\mathbf{2 0 1 0}$} & \multicolumn{2}{c|}{$\mathbf{2 0 1 1}$} \\
\cline { 2 - 8 } & \multicolumn{1}{c|}{ Value } & Rank & \multicolumn{1}{c|}{ Value } & \multicolumn{1}{c|}{ Rank } & Value & Rank \\
\hline Riga region & 0.956 & 1 & 0.786 & 1 & 0.839 & 1 \\
\hline Vidzeme region & -0.803 & 4 & -0.724 & 4 & -0.605 & 4 \\
\hline Kurzeme region & -0.701 & 3 & -0.577 & 3 & -0.432 & 2 \\
\hline Zemgale region & -0.508 & 2 & -0.454 & 2 & -0.500 & 3 \\
\hline Latgale region & -1.164 & 5 & -0.838 & 5 & -1.203 & 5 \\
\hline
\end{tabular}

Source: Report of Ministry of Economics republic of Latvia 2011 
When comparing the values of the territorial development level index according to the 2011 data against those of 2010, it emerges that the development index in the range of positive values increased for two cities Jurmala and Ventspils - whereas in the negative range this was only true for one city, Daugavpils.

Table 5. The territorial development level index of national cities

\begin{tabular}{|l|l|l|l|l|l|l|}
\hline \multirow{2}{*}{\multicolumn{1}{|c|}{ Cities }} & \multicolumn{2}{c|}{$\mathbf{2 0 0 9}$} & \multicolumn{2}{c|}{$\mathbf{2 0 1 0}$} & \multicolumn{2}{c|}{2011} \\
\cline { 2 - 8 } & \multicolumn{1}{|c|}{ Value } & \multicolumn{1}{c|}{ Rank } & \multicolumn{1}{c|}{ Value } & \multicolumn{1}{c|}{ Rank } & \multicolumn{1}{c|}{ Value } & \multicolumn{1}{c|}{ Rank } \\
\hline Riga & 0.288 & 2 & 0.291 & 2 & 0.281 & 3 \\
\hline Daugavpils & -0.504 & 6 & -0.693 & 6 & -0.680 & 6 \\
\hline Jekabpils & -0.809 & 7 & -0.709 & 7 & -0.829 & 7 \\
\hline Jelgava & 0.133 & 3 & 0.213 & 4 & 0.030 & 5 \\
\hline Jurmala & 0.536 & 1 & 0.505 & 1 & 0.736 & 1 \\
\hline Liepaja & -1.417 & 8 & -1.209 & 8 & -1.222 & 8 \\
\hline Rezekne & -1.585 & 9 & -1.796 & 9 & -1.931 & 9 \\
\hline Valmiera & 0.053 & 5 & 0.215 & 3 & 0.126 & 4 \\
\hline Ventspils & 0.118 & 4 & 0.037 & 5 & 0.359 & 2 \\
\hline
\end{tabular}

Source: Report of Ministry of Economics republic of Latvia 2011

The positive index value of Riga, Valmiera and Jelgavain turn decreased, while the negative values declined for Jekabpils, Liepaja and Rezekne. Within the three-year period of 2009 to 2011, Jurmala consistently displayed the highest values of the territorial development level index among Latvia's cities, and Rezekne had the lowest values; furthermore, the index value in 2011 increased for Jurmala and decreased for Rezekne.

\subsection{Aspects of municipality budget}

Most of a region's finances are presented as the budgets of municipalities, which are generated and used to meet the regional socio-economic needs. This calls for further study of regional finances, a number of challenges related to the development of methods for their formation and use. In the economy, the movement of all financial flows is always tied to particular territories, as it reflects the results of the interaction of specific institutional units. In Latvia, there are significant differences between the levels of development of the regions. As theim portance of regional aspects of economic development grows, the focus moves obviously to the formation and use of regional financial resources as an essential element of the social and economic development of a region. Financial resources are an indicator of the economy and highlight the most preferred areas of socio-economic development of the country and its regions. Their formation and use affect the proportion of distribution of funds between the sectors of the economy, the level of available financial resources to enterprises. Accordingly, the complex social and economic development of the country depends on the method of building the financial resources and the optimal choice of directions of their use. Since between Latvian municipalities there are significant differences in the financial opportunities, since 1995 a mechanism of equalization of Local Government Finances has been applied. The data below is based on the reports of the Ministry of Environmental Protection and Regional Development, in which one can see significant differences in the structure of revenues and expenditures of local governments in the major cities and whole regions. The structure of local government income and expenditure varies in different countries and so does the level of budget autonomy, mainly characterized by the local governments' rights to establish their own taxes, tax rates, other income, proportion of their own income, and the right to make decisions regarding their expenses (Vaidere, Vanags, Vilka, 2006: 169). 
Table 4. Volume of municipality principal budget, tax revenue and expenditure of the principal budgetin breakdown by planning region in 2011 (million LVL)

\begin{tabular}{|l|l|l|l|l|l|l|}
\hline Planning regions & $\begin{array}{c}\text { Principal } \\
\text { budget } \\
\text { revenue }\end{array}$ & $\begin{array}{c}\text { Tax } \\
\text { revenue }\end{array}$ & $\begin{array}{c}\text { Proportion of } \\
\text { tax revenue in } \\
\text { principal budget } \\
\text { revenue, } \\
\text { \% }\end{array}$ & $\begin{array}{c}\text { Principal } \\
\text { budget } \\
\text { expenditure }\end{array}$ & $\begin{array}{c}\text { Capital } \\
\text { expenditure }\end{array}$ & $\begin{array}{c}\text { Proportion of } \\
\text { expenditure in } \\
\text { principal budget } \\
\text { expenditure, } \\
\text { \% }\end{array}$ \\
\hline Riga region & 708.85 & 476.68 & 67.2 & 708.90 & 124.17 & 17.5 \\
\hline Vidzeme region & 154.71 & 58.64 & 37.9 & 161.43 & 46.11 & 28.6 \\
\hline Kurzeme region & 183.66 & 83.91 & 45.7 & 187.24 & 51.79 & 27.7 \\
\hline Zemgale region & 167.05 & 77.93 & 46.7 & 175.03 & 44.62 & 25.5 \\
\hline Latgale region & 201.18 & 66.85 & 33.2 & 216.33 & 66.34 & 30.7 \\
\hline Total & $\mathbf{1 4 1 5 . 4 4}$ & $\mathbf{7 6 4 . 0 1}$ & $\mathbf{5 4 . 0}$ & $\mathbf{1 4 4 8 . 9 3}$ & $\mathbf{3 3 3 . 0 4}$ & $\mathbf{2 3 . 0}$ \\
\hline
\end{tabular}

Source: prepared by the authors

The budget income of Latvian republic-scale cities and municipalities is formed by deductions from the national taxes and duties, municipality duty, state budget subsidies and targeted subsidies, grants from the municipal finance equalization funds, payments to municipality budgets, payment for services, deductions from enterprise profits, income from rent of municipal property, property sale, and other income defined by legislation (Law on Municipality Budgets, 1995). In 2011, the highest municipality revenue among the planning regions - exceeding that of other regions significantly - was in the Riga region, whereas Latgale had by far the lowest revenue. A summary of self-government expenditures by planning region reveals that, in 2011, the Riga region had the highest capital expenditure in the principal budget in terms of volume, and the Zemgale region had the lowest, and the same applied to the year 2010. The highest share of capital expenditure in the principal budget was in the Latgale region (30.7\%) and the lowest was in the Riga region (17.5\%).

As significant disparities exist in the financial capacity of municipalities, equalisation of self-government finances has been performed since 1995. In Latvia, financial equalisationin municipalities can be justifiably regarded as one of the key instruments of regional development, aimed at reducing unfavorable disparities among municipalities. According to the law, the calculation of equalization of Local Government Finances was conducted in the following sequence:

- Calculation of income of each local government.

- Calculation of financing needs of each local government.

- Determining equalization payments to the fund.

- Determining the amount of subsidies paid from the equalization fund.

- Calculation of the required amount of grants made from the state budget.

Evaluation is performed for each local government separately, within the respective municipal group (Law on Local Government Finances Alignment, 1998). The amounts of public subsidies did not change from 2001 to 2010 and accounted for 7.2 million lats in 2011, while the government subsidies increased from 7.9 million lats in 2012 to 8.4 million lats. Thus from the point of view of development of Latvia's regions, the use of the mechanism of financial equalization provides a reduction of differences between regions, as government support is provided where the level of development is lower.

\section{Conclusions}

The problem solving of regional finance defines emerging new approaches to the management of territories, which is associated with a greater differentiation in the levels of socio-economic development of regions and their municipalities. This fact complicates the formation of the necessary system of sufficiently flexible approaches to socio-economic development of regions and territories, including the use of instruments of regional finance and fiscal policy. There is a need to study the region's financial resources, and 
the mechanism of their functioning, create maximally good conditions for future growth, and finding the reserves for their formation directly affects the efficiency of the use of financial resources.

\title{
References
}

Economic Development of Latvia. (2012). Report of Ministry of Economics Republic of Latvia. Economic Development of Latvia. (2010). Report of Ministry of Economics Republic of Latvia. Economic Development of Latvia. (2009). Report of Ministry of Economics Republic of Latvia.

The proportion of unsuccessful loan applications by SMEs has risen with the economic crisis. (2011). Eurostat newsrelease, No. 144.

SME policies in EU. Website: http://www.mvu.lv/pub/?id=11

SME available EU initiatives and programmes. Website: http://www.mvu.lv/pub/?id=12

Pande, J. (2009). Enterprising Entrepreneurship: Concepts and Guidelines. Delhi, IND: Global Media, p. 137.

The Latvian Central Statistical Bureau database. Website: http://data.csb.gov.lv

Boadway, R. (2006). Intergovernmental Fiscal Transfers: Principles and Practice. Herndon, VA, USA: World Bank Publications, p. 361.

Development of Regions in Latvia. (2011). Report of Ministry of Environmental Protection and Regional Development. State Regional Development Agency, p. 81-84.

Doing Business data for Latvia. (2013).

Doing Business data for Latvia. (2012).

Doing Business data for Latvia. (2011).

Vaidere, I., Vanags, E., Vanags, I., Vilka, I. (2006). Regional politics and development of local governments in European Union and Latvia, p. 169.

Law on Municipality Budgets. (1995). Republic of Latvia, 18.04.1995.

Law on Local Government Finances Alignment. (1998). Republic of Latvia, 05.03.1998.

The Latvian Central Statistical Bureau database. Website: http://data.csb.gov.lv

Blaug, M. (1994). Economic Theory in Retrospect. Moscow, p. 616-617.

Schumpeter, J. A. (1982). The Theory of Economic Development: An Inquiry into Profits, Capital, Credit, Interest, and the Business Cycle. Moscow, p. 63.

Isenberg, D. (2011). The Entrepreneurship Ecosystem Strategy as a New Paradigm for Economic Policy: Principles for Cultivating Entrepreneurship. Based on an invited presentation at the Institute of International and European Affairs.

\section{SMULKIOJO IR VIDUTINIO VERSLO PLËTRA LATVIJOS REGIONUOSE}

\author{
Inese Ratanova, Galina Reshina, Silvija Bruna, Eduards Gross
}

Tarptautinė Baltijos akademija (Latvija), Latvijos universitetas (Latvija)

\section{Santrauka}

Norint sèkmingai pereiti į naują ekonominio vystymosi etapą būtina gerinti verslo sąlygas, reikia ir tokių verslininkų, kurie būtų pasirengę pradèti verslą ir steigti naujas bendroves. Viena pagrindinių užduočių, su kuriomis susiduria ES narès - verslumo konkurencingumo didinimas. Tai vieni pagrindinių tikslų, iškeltų ES 2000 metais Lisabonoje, siekiant pagerinti ES padètị užimtumo, ekonominiu reformų ir socialinès sanglaudos srityse. Verslumas - tai ne tik varomoji darbo vietų kūrimo jëga, jis taip pat didina konkurencinguma, užtikrina plètra, leidžia realizuoti save ir siekti socialinių tikslų. Autoriai ypatingą dèmesį kreipia ị veiksnius, nulemiančius verslo sąlygas ir verslumą Latvijos regionuose.

PAGRINDINIAI ŽODŽIAI: regionu vystymas, smulkus ir vidutinis verslas. 